\title{
Chemical Assessment of White Wine during Fermentation Process
}

\author{
Teodora Emilia COLDEA, Elena MUDURA*, Carmen CHIRCU, Andrei BORŞA \\ Faculty of Food Science and Technology, University of Agricultural Sciences and Veterinary Medicine, 400372, \\ Cluj-Napoca, Romania \\ elena.mudura@usamvcluj.ro
}

Bulletin UASVM Food Science and Technology 71(1) / 2014

ISSN-L 2344-2344; Print ISSN 2344-2344; Electronic ISSN 2344-5300

\begin{abstract}
There were investigated chemical properties of indigenous white wine varieties (Fetească albă, Fetească regală and Galbenă de Odobești) during fermentation. The white wine making process took place at Wine Pilot Station of University of Agricultural Sciences and Veterinary Medicine Cluj-Napoca. We aimed to monitored the evolution of fermentation process parameters (temperature, alcohol content, and real extract) and the quality of the bottled white wine (total acidity, alcohol content, total sulfur dioxide, total dry extract). The results obtained were in accordance to Romanian Legislation.
\end{abstract}

Keywords: white wine, chemical parameters, fermentation process monitoring.

\section{INTRODUCTION}

Wine includes a variety of compounds that influence its quality. These compounds originate from both raw materials and wine obtaining biotechnological processes. Alcoholic fermentation of white grape must, along with care treatments, conditioning and maturation applied have a direct influence on the physico-chemical and aroma compounds (Jones et al., 2008; Komes et al., 2007; Muñoz-González et al., 2011; Suzzi et al., 2012). Pérez-Coello et al. (2000) tested the fermentation of white wines in the presence of wood chips. Several studies had evaluated the impact of applied ageing techniques to white wines (Spillman et al., 1997; Fernández-Novales et al., 2009).

Romanian white wine comes from old times, reaching us through a dowry of native varieties (Fetească albă, Fetească regală, Grasă de Cotnari, Tămâioasă românească, Frâncuşă de Cotnari, Galbenă de Odobești), being the subject of different researches (Ghiță et al., 2012; Itu et al., 2011).

In the present study we aimed to evaluate the parameters evolution which influenced the white wines fermentation process of indigenous grape varieties (Fetească albă, Fetească regală, Galbenă de Odobeşti) at Wine Pilot Station of University of Agricultural Sciences and Veterinary Medicine Cluj-Napoca.

Feteasca alba is the most widespread variety in Romanian vineyards. The sugar content easily exceeds $200 \mathrm{~g} / \mathrm{L}$, but with low acidity. This deficiency have to be correct in must processing, followed by low temperature fermentation. Fetească alba has not a great personality; it is a wine without a specific flavor variety, but is instead chosen a fine wine, round, soft, ample, full-bodied.

Feteasca regala is one of the most appreciated domestic grape varieties, native to Transilvania. The Fetească regala variety is an evolution Fetească alba; more specifically, it's a naturally occurring genetic evolution.

Grasa de Cotnari is an old vine variety from renowned vineyard Cotnari. It is considered that this variety is the most valuable in terms of quality, but has a relatively small area of culture. Grasa de Cotnari has thin and delicate skin; is very sensitive to attack by Botrytis cinerea. In warm and dry autumn the grapes touch easily sugars concentrations above $250 \mathrm{~g} / \mathrm{L}$; the wine obtained shows the specific character. 


\section{MATERIALS AND METHODS}

Provenience of samples

Three indigenous white grape varieties were used in producing wine at University of Agricultural Sciences and Veterinary Medicine Cluj-Napoca - Wine Pilot Station: Fetească Albă, Fetească Regală and Galbenă de Odobești, from the Vrancea region, located in the South-East part of Romania.

Grapes reception involved quantitative and qualitative analysis (health control, sugar content and total acidity). In order to obtain the must, grapes were destemmed and crushed, then subjected to pressing. Skins and seeds were eliminated (Fig. 1).

Grape must was treated with sulfite and racked in tank. For clarifying, must was then cooled to 12 ${ }^{\circ} \mathrm{C}$. The clarified grape must was transferred to the fermentation tank. Because of spontaneous flora present on the surface of grains, alcoholic fermentation started, grape must temperature rising to $16{ }^{\circ} \mathrm{C}$. The must was inoculated with selected Saccharomyces cerevisiae starter culture
(15 g/hL). Grape must was then cooled, and the entire period of fermentation, temperature was maintained at $10-12{ }^{\circ} \mathrm{C}$. The whole fermentation process was monitored by evaluating the following parameters: temperature, total acidity, apparent extract, total extract, alcohol content, relative density and sulfur dioxide.

Thealcoholicfermentation was stopped (attotal extract $<4 \%$ ) by sulfitation. After a resting period (with cold and protein stabilization), wine was racked in another tank and bentonized. Sulfitation was conducted in order to keep a maximum limit of $20 \mathrm{mg}$ total SO2/L wine (according to Romanian legislation). Double filtration was carried out (removing of fine particles and sterile filtration). The bottled wine was analyzed to establish the physical and chemical characteristics of the finished product.

Figure 1 describes the flow diagram of white wine making process.

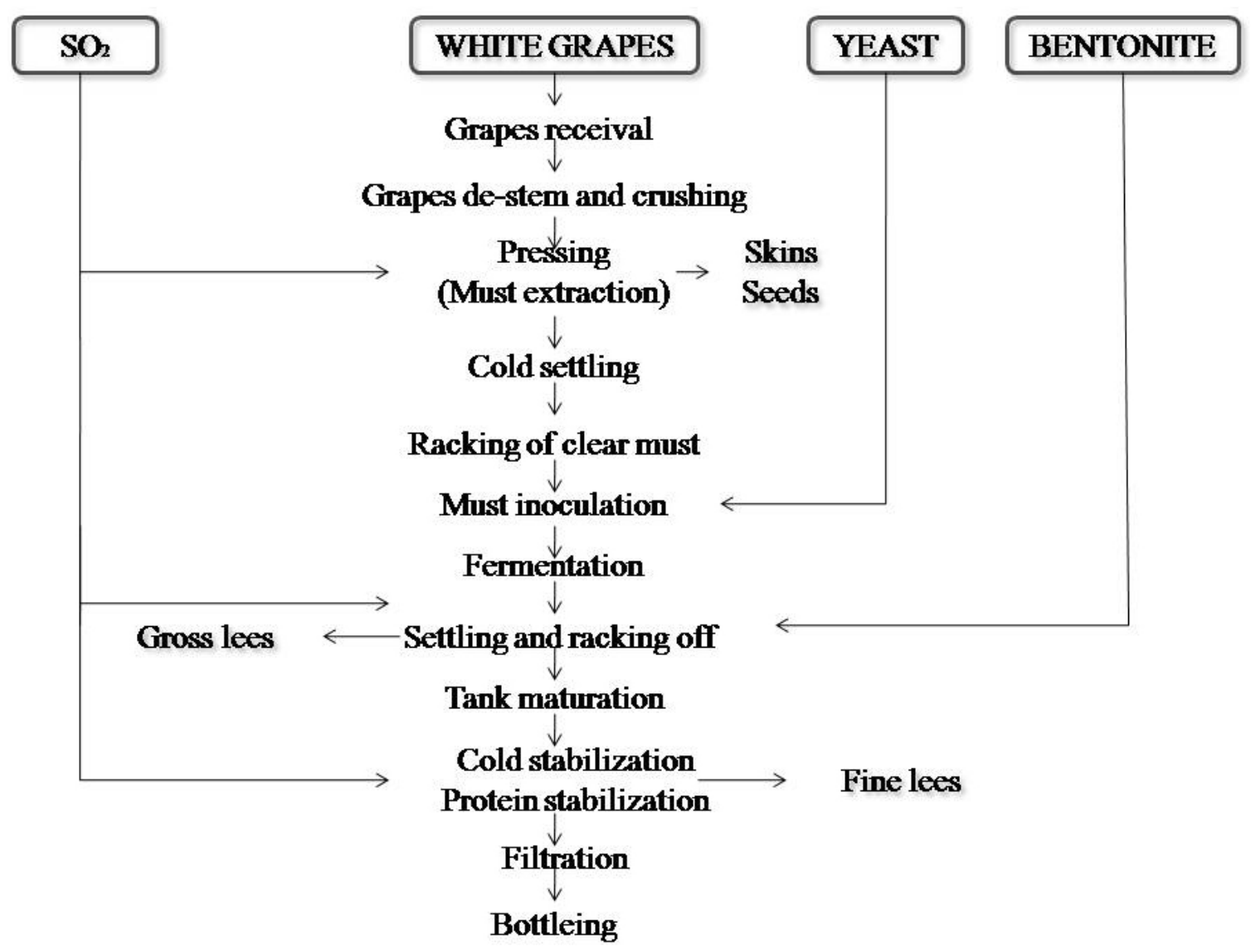

Fig. 1. Flow diagram of white wine making process 


\section{Description of the analyzed parameters}

The alcohol content (expressed in \% vol.) refers to the amount of ethanol produced from the grape must extract - fermentable saccharides - by the fermentation yeasts.

Must extract (original proof extract) - expressed in weight percentage (\% wt) -represent the content of the solid substances found in original grape must at the beginning of the fermentation.

The real extract refers to the content of the dissolved substances in the de-carbonated grape must, expressed in \% wt.

The apparent extract ( $\% w t$.) was determined in the presence of alcohol which influences it. Their value is smaller than the total extract and indicates the stage of fermentation.

\section{The monitoring of the fermentation parameters}

Analytical methods

Sugar content was determined at the reception of grapes using a digital refractometer type DR201-95 (Kruss, Germany) (STAS 6182/9-80).

Fermentation process was monitorized by the evolution of alcohol content, original proof extract, relative density and temperature. Before each analyze, wine samples were filtered and freed of carbon dioxide by means of Erlenmeyer shaking flask.

Alcohol content, grape must extract (real and apparent extracts), and relative density were evaluated using the automatic analyzer Fermentostar (Funke-Gerber, Germany). This device is suitable for all types alcohol fermentation resulted beverages: alcohol content (0.00-15.00 $\%$ vol.); real extract (0.00-10.00 \% wt.); apparent extract (0.00-10.00\% wt.); wort (0.00-20.00 $\%)$; relative density $(0.95-1.05 \mathrm{~g} / \mathrm{cm} 3)$. The measurement is based on methods of thermo- analytical measuring combined with mathematical algorithms. The accuracy of each measurement resolution defined by the manufacturer is 0.01 $\%$ for each parameter. The wine sample (20 $\mathrm{ml}$ ), prepared as described before was sucked into a measuring cell by means of a pump. Alcoholic content, extract and relative density were measured using thermal measuring effects. Constituents thereby derived such as original wort and apparent extract were likewise determined. The result appeared on the apparatus screen.

All analyses were developed in order to verify their accordance with Romanian Legislation for wines (Tab. 1).

The measurement of $\mathrm{pH}$ was carried out using the $\mathrm{pH}$ meter type $\mathrm{pH} 315 \mathrm{i}$ (WTW $\mathrm{GmbH}$, Weilheim). Temperature was measured using the thermometer set on the fermentation tank. Total sulfur dioxide and total acidity were measured by common titration methods. Total dry extract was determined using the refractometric method (STAS 6182/9-80).

\section{Statistical analysis and evaluation of the results}

All analytical measurements were performed in triplicate. The values of the parameters are expressed as the mean \pm standard deviation. In order to evaluate the relation between variables, the Pearson correlation coefficient was used (Codină et al., 2013).

\section{RESULTS AND DISCUSSIONS}

In the Table 2 shown below are presented values determined at the reception of grapes.

The collected samples were tested by means of the automatic analyzer Fermentostar to determine the real extract, apparent extract, alcohol content and original proof of the grape must.

Table 1. Romanian legislation applied for wine quality parameters (alcohol content, total acidity, sulfur dioxide)

\begin{tabular}{lc}
\hline \multicolumn{1}{c}{ Quality parameter } & Admissible value \\
\hline Alcohol content, \% vol. & Min. 8.5 \\
\hline Total acidity $\left(\mathrm{H}_{2} \mathrm{SO}_{4} \mathrm{mg} / \mathrm{L}\right)$ & Max. 15 \\
\hline Sulfur dioxide, $\mathrm{mg} / \mathrm{L}$ & Min. 2.28 \\
Dry red wines & Max. 150 \\
Dry white and rose wines & Max. 210 \\
Demi-dry white and rose wines & Max. 260 \\
\hline
\end{tabular}


As seen in the Table 3, there were considerable variations during the period Day 5-25. These variations are related to the slightly fluctuations values of real extract, temperature and the period of fermentation. Values of the Day 24 represent the samples before filtering, and Day 25, the analysis taken on the bottled wine. Alcohol content in the bottled wine was $10.73 \%$ vol. Very strong positive correlation was given between alcohol content and original proof extract $(r=0.939)$ and very strong negative correlation was determined between alcohol content - real extract $(r=-0.999)$, alcohol content - relative density $(r=-0.997)$ and alcohol content - apparent extract $(r=-0.999)$. The statistical analysis demonstrated the growing dependence of the ethanol content on the extract concentration.

Besides these fermentation parameters, total sulfur dioxide and total dry extract were determined on the bottled wine (Tab. 4).

Our results were in accordance with previous studies (Nurgel et al., 2002) and Romanian legislation $(244 / 2002)$.

Table 2. Sugar content and total acidity as determined at fruit receival

\begin{tabular}{lcc}
\hline \multicolumn{1}{c}{ Parameter } & Method & Value obtained \\
\hline Sugar content, g/L & Refractometric & 179 \\
\hline Total acidity (expressed in H2SO4), g/L & Titration & 4.06 \\
\hline
\end{tabular}

Table 3. The mean values and standard deviation of the alcohol content, original proof extract, total extract, apparent extract and relative density in the fermented grape must samples taken from USAMV Cluj-Napoca - Wine Pilot Station

\begin{tabular}{|c|c|c|c|c|c|c|c|c|c|}
\hline Paran & ( & ay 10 & Day 10 & ay 17 & ay 19 & Day 20 & Day 21 & $x_{2}=1$ & ay zu \\
\hline & & & & & & & & & \\
\hline & & & & & & & & & \\
\hline & & & & & & & $\begin{array}{c}5.38 \\
( \pm 0.09) \\
\end{array}$ & & \\
\hline & $\begin{array}{c}13.57 \\
( \pm 0.14)\end{array}$ & $(-0.10)$ & 6.75 & $\begin{array}{c}4.78 \\
( \pm 0.30)\end{array}$ & $\begin{array}{r}3.45 \\
( \pm 0.06 \\
\end{array}$ & $\begin{array}{c}2.65 \\
( \pm 0.16)\end{array}$ & $\begin{array}{c}2.40 \\
( \pm 0.07)\end{array}$ & $\begin{array}{r}1.19 \\
( \pm 0.19\end{array}$ & $\begin{array}{c}1.35 \\
( \pm 0.16)\end{array}$ \\
\hline $\begin{array}{l}\text { Relative } \\
\text { density, g/mL }\end{array}$ & $\begin{array}{l}1.0625 \\
( \pm 0.00)\end{array}$ & $\begin{array}{l}1.0621 \\
( \pm 0.00)\end{array}$ & $\begin{array}{l}1.0243 \\
( \pm 0.00)\end{array}$ & $\begin{array}{l}1.0156 \\
( \pm 0.00)\end{array}$ & $\begin{array}{l}1.0081 \\
( \pm 0.00)\end{array}$ & $\begin{array}{l}1.0032 \\
( \pm 0.00)\end{array}$ & $\begin{array}{l}1.0016 \\
( \pm 0.00)\end{array}$ & $\begin{array}{l}0.9927 \\
( \pm 0.00)\end{array}$ & $\begin{array}{l}0.9941 \\
( \pm 0.00)\end{array}$ \\
\hline
\end{tabular}

Table 4. The values on the finished product (Day 25) - sulfur dioxide and total dry extract (g/L)

\begin{tabular}{lcc}
\hline \multicolumn{1}{c}{ Parameter } & Method & Value obtained \\
\hline Total sulfur dioxide, g/L & Titration & 133.12 \\
\hline Total dry extract, g/L & Refractometric & 20.13 \\
\hline $\mathrm{pH}$ & $\mathrm{pH}$ meter & 3.4 \\
\hline
\end{tabular}




\section{CONCLUSION}

Three indigenous white grape varieties were used in making white wine at USAVM Cluj-Napoca Wine Pilot Station (Fetească Albă, Fetească Regală and Galbenă de Odobești), from the Vrancea region, located in the South-East part of Romania. The technological process was monitorized in order to asses to evolution of the fermentation parameters (ethanol content, real extract and relative density) to obtain a white wine with specific parameters.

\section{REFERENCES}

1. Codină, G.G. et al., (2013). Multivariate analysis of wheat flour dough sugars, gas production, and dough development at different fermentation times, Czech J. Food Sci., 31:222-229.

2. Fernández-Novales, J. et al. (2009). Shortwave-near infrared spectroscopy for determination of reducing sugar content during grape ripening, winemaking, and aging of white and red wines, Food Res. Int., 42:285-291.

3. Ghiță, A.G. et al. (2012). Research concerning the application of some technological white wine conditioning measures meant to stabilise it, Journal of Horticulture, Forestry and Biotechnology, 16:49-52.

4. Itu, N.L., et al. (2011). Effect of maceration enzymes addition on the aromatic white winemaking, The Annals of the University Dunarea de Jos of Galati, 35:77-91.
5. Jones, P.R. et al. (2008). The influence of interactions between major white wine components on the aroma, flavour and texture of model white wine, Food Qual. Prefer., 19:596-607.

6. Komes, D. et al. (2007). Study of phenolic and volatile composition of white wine during fermentation and a short time of storage, Vitis, 46:77-84.

7. Muñoz-González, C. et al. (2011). Volatile and sensory characterization of Xarel.lo white wines, Flavour Flag. J., 26:153-161.

8. Nurgel, C. et al. (2002). Influence of Saccharomyces cerevisiae strains on fermentation and flavor compounds of white wines made from cv. Emir grown in Central Anatolia, Turkey, J. Ind. Microbiol. Biot., 29:28 - 33.

9. Pérez-Coello, M.S. et al.(2000). Fermentation of white wines in the presence of wood chips of American and French oak, J. Agric. Food Chem., 48:885-889.

10. Spillman, P.J. et al. (1997). Accumulation of vanillin during barrel-aging of white, red, and model wines, J. Agric. Food Chem., 45: 2584-2589.

11. Suzzi, G. et al. (2012). Multistarter from organic viticulture for red wine Montepulciano d'Abruzzo production, Front. Microbiol., Available at: http://www. ncbi.nlm.nih.gov/ pmc/articles/PMC3328976/. Accessed 2014 Apr. 28.

12. ***Legea viei și vinului în sistemul organizării comune a pieţei vitivinicole, legea nr. 244/2002 republicată în 2007.

13. ${ }^{* * *}$ STAS 6182/9-80. Vin. Determinarea extractului sec total. 